\title{
Cranial Magnetic Resonance Imaging as a Screening Tool for Evaluation of Silent Brain Ischemia in Severe Coronary Artery Disease: A Clinical Based Study
}

\author{
Ciddi Koroner Arter Hastalığında Sessiz Beyin İskemisini Değerlendirmede Tarama Aracı Olarak \\ Kranial Manyetik Rezonans Görüntüleme: Klinik Tabanlı Bir Çalışma
}

Tuğba İlkem KURTOĞLU ÖZCAĂLAYAN ${ }^{1}$

(D) 0000-0003-3849-1194 Demet ÖZKARAMANLI GÜR2

(1) 0000-0003-2542-8196

Ömer ÖZÇAĞLAYAN ${ }^{1}$

(D) 0000-0001-5036-4919

Birol TOPÇU $\mathbf{U}^{3}$

(D) 0000-0003-0771-2505

Aysun ÜNAL ${ }^{4}$

(D) 0000-0002-7702-8437

\begin{abstract}
${ }^{1}$ Tekirdağ Namık Kemal University, Faculty of Medicine, Department of Radiology, Tekirdağ, Turkey

${ }^{2}$ Tekirdağ Namık Kemal University, Faculty of Medicine, Department of Cardiology, Tekirdağ, Turkey

${ }^{3}$ Tekirdağ Namık Kemal University, Faculty of Medicine, Department of Biostatistics, Tekirdağ, Turkey

${ }^{4}$ Tekirdağ Namık Kemal University, Faculty of Medicine, Department of Neurology, Tekirdağ, Turkey
\end{abstract}

\section{Corresponding Author Sorumlu Yazar Tuğba İlkem KURTOĞLU ÖZÇAĞLAYAN \\ drtugbailkem@yahoo.com}

Received / Geliş Tarihi : 06.07.2020 Accepted / Kabul Tarihi : 20.11.2020 Available Online /

Çevrimiçi Yayın Tarihi : 25.12.2020

\begin{abstract}
Aim: Silent brain ischemia (SBI), defined as ischemic changes and infarcts without neurologic signs, is an established marker of poor survival. Magnetic resonance imaging (MRI) is useful to define SBI and white matter hyperintensities that correspond to microangipathic ischemic disease. This study aimed to investigate the relationship among SBI, white matter lesions and the extent of coronary artery disease (CAD), and to determine possible predictors of SBI. Material and Methods: A total 10640 patients who underwent coronary angiography were retrospectively screened to reveal 312 patients who had been evaluated with a subsequent cranial MRI within 6 months. CAD severity was established with Gensini score and MRIs were evaluated to determine presence of SBI and white matter hyperintensities scored by Fazekas. Finally, 58 patients with SBI and 254 without SBI consisted SBI and non-SBI groups. Results: Patients with SBI were significantly older with higher prevalence of male gender than the non-SBI patients. Both Gensini and Fazekas scores were higher in SBI-group $(\mathrm{p}<0.001)$. Fazekas score was positively correlated with Gensini score $(r=0.219, p<0.001)$ and age $(\mathrm{r}=0.465, \mathrm{p}<0.001)$. In the logistic regression analysis; age, male gender and Gensini score were identified as the independent predictors of SBI.

Conclusion: Although SBIs don't present neurological symptoms they are associated with poor survival and future stroke. Our data suggest that cranial MRI may be a screening tool in risk stratification, particularly in elderly male patients with multivessel CAD. Our study also depicted that age, male gender and high Gensini scores are the independent predictors of SBI. Keywords: Brain ischemia; coronary angiography; coronary artery disease; magnetic resonance imaging; stroke.
\end{abstract}

öz

Amaç: Nörolojik bulgu göstermeyen iskemik değişiklikler ve enfarktlar olarak tanımlanan sessiz beyin iskemisi (SBI), kötü sağ kalımın bilinen bir göstergesidir. Manyetik rezonans görüntüleme (MRG), SBI ve mikroanjiopatik iskemik hastalığa karşılık gelen beyaz madde hiperintensitelerini göstermede yararlı bir yöntemdir. Bu çalışmada SBI, beyaz madde lezyonları ile koroner arter hastalığı (KAH) arasındaki ilişkiyi araştırmak ve SBI'nın olası belirleyicilerini belirlemek amaçlanmıştır.

Gereç ve Yöntemler: Koroner anjiyografi yapılan toplam 10640 hasta retrospektif olarak taranarak 6 ay içerisinde müteakip olarak kranial MRG ile değerlendirilmiş 312 hasta belirlendi. KAH ciddiyeti Gensini skoru ile tespit edildi ve MRG'ler SBI varlığı ile Fazekas skoru ile ölçülen beyaz madde hiperintensiteleri açısından değerlendirildi. Bunun sonucunda SBI olan 58 ve SBI olmayan 254 hasta, SBI ve SBI olmayan hasta gruplarını oluşturdu.

Bulgular: SBI olan hastalar, SBI olmayan hastalardan anlamlı şekilde daha yaşlı ve daha yüksek prevalansta erkek cinsiyette idi. SBI grubunda hem Gensini hem de Fazekas skorları daha yüksekti $(p<0.001)$. Fazekas skoru, Gensini skoru $(r=0,219 ; p<0,001)$ ve yaş $(r=0,465$; $\mathrm{p}<0,001)$ ile pozitif korelasyonlu idi. Lojistik regresyon analizinde; yaş, erkek cinsiyet ve Gensini skoru, SBI'nın bağımsız belirteçleri olarak belirlendi.

Sonuç: SBI nörolojik semptom göstermese de, kötü sağ kalım ve ileride yaşanacak inme ile ilişkilidir. Bulgularımız, kranial MRG'nin özellikle çoklu damar KAH olan yaşlı erkeklerde risk değerlendirmesi için bir tarama aracı olabileceğini göstermektedir. Çalışmamız ayrıca yaş, erkek cinsiyet ve yüksek Gensini skorunun SBI'nın bağımsız belirteçleri olduğunu göstermiştir. Anahtar kelimeler: Beyin iskemisi; koroner anjiyografi; koroner arter hastalığı; manyetik rezonans görüntüleme; inme.

Presented as an abstract at $29^{\text {th }}$ Annual Meeting of Turkish Society of Neuroradiology on Neuroradiology and Head and Neck Radiology, (February 14-16, 2020, Istanbul, Turkey) 


\section{INTRODUCTION}

Silent brain ischemia (SBI) refers to brain disorders that are incidentally found in imaging modalities but do not cause significant neurological deficits $(1,2)$. It is one of the manifestations of silent cerebrovascular disease which is a common finding in brain scans and calls attention to future stroke or dementia. Among other manifestations of silent cerebrovascular disease in neuroimaging is white matter hyperintensities that correspond to microangiopathic ischemic disease. SBI, on the other hand, is described as "a cerebral infarction that is evident by brain imaging but that is without a clinical syndrome characterized by rapidly developing clinical symptoms and signs of focal and at times a global loss of brain function" (3). It is not a rare entity with an estimated prevalence of $10-20 \%$ (4).

Although SBIs do not cause clinical symptoms, they are known to be closely associated with impending stroke (5). In addition, while SBIs do not result in focal neurological deficits, they have been shown to be related with neurocognitive and neuropsychiatric impairment and increase mortality $(6,7)$. Nevertheless, the pathophysiology of SBIs remains unclear and various causes, such as small vessel disease, disorders of blood brain barrier, embolism or hypo perfusion have been suggested. Associated predisposing factors such as carotid atherosclerosis, heart failure or coronary artery disease (CAD) could have been identified.

SBIs present as hyperintense lesions on T2-weighted Magnetic resonance imaging (MRI), hyperintense gliotic rims on the fluid-attenuated inversion recovery (FLAIR) sequence, and diffusion-restricted acute lesions on diffusion-weighted imaging (DWI) (8). Although some studies have used computed tomography (CT) in their analyses (9), MRI has been shown to be more specific and sensitive in its ability to distinguish SBIs from enlarged perivascular spaces (6).

While prior studies have assessed the relationship between CAD and symptomatic cerebrovascular disease, the relationship of SBI with presence and extent of coronary atherosclerosis scored by Gensini scoring or brain deep white matter microangiopatic disease graded using Fazekas classification has not been evaluated yet. As such, the current study aimed to evaluate the possible associations of silent cerebrovascular disease in the form of SBI and brain white matter microangiopathic lesions with severity and extent of CAD. It also sought to investigate the distribution of localizations of such lesions within brain as well as to define the predictors of SBI.

\section{MATERIAL AND METHODS}

This study was approved by ethics committee of Namık Kemal University Faculty of Medicine in 30/11/2017 with 2017/94/10/09 approval number. Following ethics approval, coronary angiographic examinations that had been performed at the cardiology department between November 2015 and November 2018 were retrospectively evaluated. Of 10640 coronary artery examinations found in the hospital database, patients who had undergone subsequent brain MRI for evaluation of neurological disorders such as headache, migraine (without neurological deficit), vertigo, tinnitus, memory difficulties, paresthesias and syncope performed within 6 months following coronary angiography were identified.
Patients with any neurological deficit, patients under 40 years of age or those already with the diagnosis of cerebrovascular disease, neurodegenerative diseases, demyelinating diseases, neoplastic diseases and vasculitis were excluded. At the end of selection procedure, 335 patients who had undergone both coronary angiography for differential diagnosis of CAD and brain MRI were identified. Of 335 patients, 8 patients who were under 40, 13 patients with diagnosis of stroke, 1 patient with lacunar infarct and 1 patient with motion artifact at the imaging were excluded from the study.

Finally, this study examined 312 patients with lesions that were detected with MRI, and the study group was categorized into two groups with regard to the presence of SBI; patients with SBI and patients without SBI (non-SBI) groups (Figure 1).

\section{Coronary Angiography Protocol}

Coronary angiography was performed as described earlier. Coronary arteries were identified as left anterior descending (LAD), circumflex $(\mathrm{Cx})$, and right coronary artery (RCA), and coronary artery lesions were evaluated quantitatively by Gensini score. CAD was also classified as 0-VD for no vessel involvement, 1-VD for the involvement of 1 vessel, 2-VD for the involvement of 2 vessels, and 3-VD for the involvement of 3 vessels, respectively. Gensini scoring was calculated by a cardiologist who was blinded to the study groups as described previously (10).

\section{Magnetic Resonance Imaging Protocol}

The cranial MRI examination was performed with the GE Healthcare TM Optima TM MR360 1.5T (Marlborough, USA). Diffusion Weigthed Imaging (DWI), T2 Weighted (T2W) images, and Fluid Attenuated Inversion Recovery (FLAIR) sequences were evaluated during the cranial MRI examination. The parameters for the T2W images were Time of Repetition (TR): $4561 \mathrm{msec}$, Time of Echo (TE): $101.9 \mathrm{msec}$, Field of View (FOV): $24 \mathrm{~cm} \mathrm{x} 19.2 \mathrm{~cm}$, Matrix: 352 x 224, Bandwidht (BW): $1.25 \mathrm{KHz}$, thickness: $5.8 \mathrm{~mm}$, gap: $1.5 \mathrm{~mm}$, and Number of Excitation (NEX): 2. The parameters for the FLAIR sequences were TI: 2070

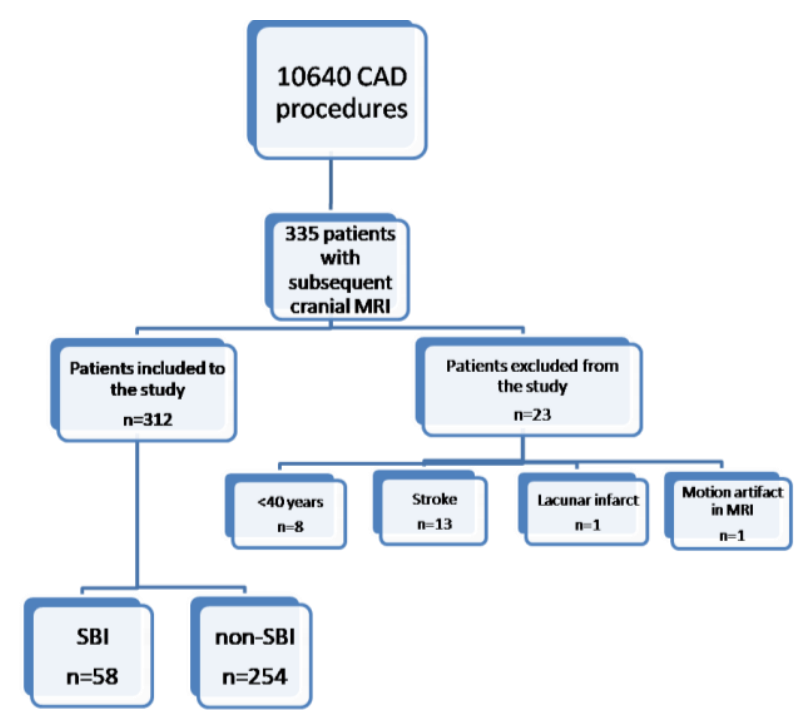

Figure 1. Flow chart of the study design. CAD: coronary artery disease, MRI: magnetic resonance imaging, SBI: silent brain ischemia 
msec, TR: $8800 \mathrm{msec}$, TE: $86.3 \mathrm{msec}$, FOV: $24 \mathrm{~cm}$ x 24 cm, Matrix: 352 x 224, BW: $1.25 \mathrm{KHz}$, thickness: $5.8 \mathrm{~mm}$, gap: $1.5 \mathrm{~mm}$, and NEX: 2. Finally, the parameters for DWI were TR: $5200 \mathrm{msec}$, TE: $106.8 \mathrm{msec}, \mathrm{BW}: 1.25 \mathrm{KHz}$, FOV: $24 \mathrm{~cm}$ x $24 \mathrm{~cm}$, Matrix: 128 x 128, and NEX: 2.

The cranial MRI examination was evaluated by an experienced neuroradiologist in a blind fashion to determine the presence of SBI and microangiopathic ischemic gliosis in the deep white matter. MRI examinations of all patients were performed during their initial evaluation. Upon the evaluation of microangiopathic ischemic gliosis, Fazekas scoring of lesions were used. In patients without any stroke symptoms, lesions larger than $3 \mathrm{~mm}$ in diameter were found to be compatible with SBI lesions, which are hyperintense on T2W images (Figure 2a) and suppressed with gliotic rim in the white matter on FLAIR sequences (Figure 2b). Lesions smaller than $3 \mathrm{~mm}$ in diameter were not identified as SBI lesions. As such, they were not included in the SBI group (11). Lesions larger than $3 \mathrm{~mm}$ in diameter but without peripheral gliotic rim were also excluded from the SBI group, receiving differential diagnoses as enlarged perivascular spaces or cystic lesions caused by brain parenchyma. In addition, the restricted diffusion of these lesions was evaluated with DWI (Figure 2c) and Apparent Diffusion Coefficient (ADC) map (Figure2d). Lesions with restricted diffusion were defined as acute lesions and were excluded from the study. Evidence of leukoaraiosis (microangiopatic ischemic gliosis) was noted during some of the cranial MRI examinations and staged according to the Fazekas scale. Lesions were evaluated according to the presence of periventricular and deep white matter lesions in $\mathrm{T} 2 \mathrm{~W}$ images and FLAIR sequences (12, Table 1).

\section{Statistical Analysis}

Statistical analyses were performed by SPSS v.17.0. The distribution of the data was determined using the Kolmogorov-Smirnov test. Normally distributed variables were presented as mean \pm standard deviation, non-normally distributed variables were presented as median, interquartile range, minimum-maximum, and categorical variables as number and percentage. The categorical variables were analyzed using the Chi-square test. The difference between numerical variables and SBI groups were assessed with Independent Samples t test or MannWhitney U test. Spearman rank correlation analysis was used to determine the relationship between Gensini score, Fazekas score and the age. Receiver operating characteristics (ROC) curve analysis was performed to find cut-off values of Gensini score for prediction of the presence of SBI lesions. Logistic regression analyses were performed to identify the predictors of SBI. By using enter method for logistic regression analysis, age, gender, Gensini score were added to the hypothesis to reveal the determinants that independently associate to SBI. A p value of $<0.05$ was accepted to be statistically significant.

\section{RESULTS}

This study provided assessments on the cranial MRIs of 312 patients. The demographic, angiographic and MRI characteristics of the study population are presented in Table 2. The mean age of the patients was $62.95 \pm 9.67$ years (range, 41-94 years). Classification of the lesions as periventricular, deep white matter or basal ganglion lesions and the dimensions of lesions are also provided in Table 3. In the SBI group, the mean size of the SBI lesions evaluated by MRI was $6.23 \pm 2.52 \mathrm{~mm}$ and these lesions were mostly localized in the frontal lobes.

There was no significant difference between the SBI and non-SBI groups in terms of cardiovascular risk factors such as hypertension, diabetes mellitus, hyperlipidemia or smoking. Nevertheless, patients with SBI were significantly older than the non-SBI patients (mean age was $69.17 \pm 10.11$ vs $61.54 \pm 9.00, p<0.001$ ). It was also revealed that the male gender was more common in the SBI group $(77.6 \%$ vs $54.3 \%, \mathrm{p}=0.001)$.

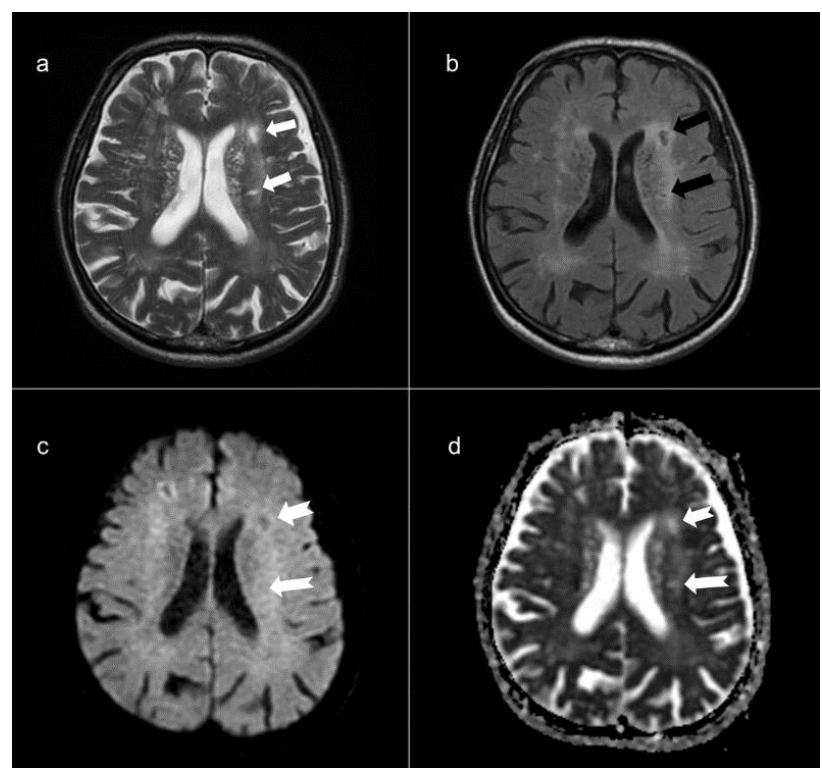

Figure 2. Axial T2W image (a) shows the hyperintense lesions with in the deep white matter (white arrows). T2W image also shows the enlarged perivascular spaces in the basal ganglia and Fazekas grade III lesions in white matter. On axial FLAIR image (b), these lesions suppressed and had gliotic rim (black arrows). Enlarged perivascular spaces have not periferic gliotic rim compared to the SBI. DWI (c) and ADC map (d) depicts that the lesions (white tailed arrows) do not show restriction of diffusion. ADC: apparent diffusion coefficient, DWI: diffusion weighted imaging, FLAIR: fluid attenuated inversion recovery, SBI: silent brain ischemia

Table 1. Fazekas classification of white matter hyperintensities on T2W and FLAIR images

\section{Deep White Matter Lesions}

0 Absent

1 Punctate foci

2 Beginning confluence

3 Large confluent areas

Periventricular White Matter Lesions
0 Absent
1 "caps" or pencil thin lining
2 Smooth "halo"
3 Irregular periventicular signal extending into the deep white matter
FLAIR: fluid attenuated inversion recovery


A significant relation was observed between the SBI and the number of VD ( 1 vs $0, p<0.001)$. While normal coronaries were more prevalent in non-SBI group $(0 \mathrm{VD}$, $\mathrm{p}<0.001), 3 \mathrm{VD}$ was more prevalent in SBI patients $(\mathrm{p}<0.001)$. The median Gensini scores of the SBI and nonSBI groups were 17 (0-128) and 5 (0-160), respectively. There was a statistically difference between the Gensini scores for the SBI and non-SBI groups, which were higher in the SBI group $(p=0.001)$. The SBI group also showed a significant statistical relationship in terms of Fazekas score, with higher grade 2 and 3 Fazekas scores $(p<0.001)$. Spearman correlation analysis demonstrated a weak positive correlation between age and both Fazekas and Gensini scores ( $\mathrm{r}=0.465, \mathrm{p}<0.001 ; \mathrm{r}=0.213, \mathrm{p}<0.001$, respectively). A weak positive correlation was also observed between Gensini score and Fazekas score $(r=0.219$, $\mathrm{p}<0.001)$. With ROC analysis, the area under curve (AUC) for performance of Gensini score to diagnose SBI lesions was measured as $0.640(95 \% \mathrm{CI}=0.560-0.719, \mathrm{p}=0.001$, Figure 3$)$. Cut off value for Gensini score was 6.25. In the logistic regression analysis conducted to determine the predictors of SBI, age, male gender and Gensini score were identified as the independent predictors of SBI $(\mathrm{p}<0.001$, Table 4$)$.

Table 2. Comparison of SBI and non-SBI groups

\begin{tabular}{lccc}
\hline & $\begin{array}{c}\text { SBI } \\
(\mathbf{n = 5 8})\end{array}$ & $\begin{array}{c}\text { non-SBI } \\
(\mathbf{n = 2 5 4 )}\end{array}$ & $\mathbf{p}$ \\
\hline Demographic characteristics & & \\
Age (years) & $69.17 \pm 10.11$ & $61.54 \pm 9.00$ & $<\mathbf{0 . 0 0 1}{ }^{\dagger}$ \\
Male Gender, n (\%) & $45(77.6)$ & $138(54.3)$ & $\mathbf{0 . 0 0 1}^{\S}$ \\
Hypertension, n (\%) & $41(70.7)$ & $189(74.4)$ & $0.561^{\S}$ \\
Diabetes mellitus, n (\%) & $30(51.7)$ & $126(49.6)$ & $0.771^{\S}$ \\
Hyperlipidemia, n (\%) & $32(55.2)$ & $138(54.3)$ & $0.908^{\S}$ \\
Smoking, n (\%) & $17(29.3)$ & $75(29.5)$ & 0.974 \\
\hline
\end{tabular}

\section{Angiographic characteristics}

Gensini Score 17 (57) $[0-128] 5$ (26) [0-160] $\mathbf{0 . 0 0 1}^{\#}$

Number of vessels $1(2)[0-3] \quad 0(1)[0-3] \quad<\mathbf{0 . 0 0 1}^{\#}$

Number of vessels, $\mathrm{n}(\%)$

\begin{tabular}{cccc}
0 & $18(31.0)$ & $141(55.5)^{*}$ & \\
1 & $18(31.0)$ & $52(20.5)$ & $<\mathbf{0 . 0 0 1}^{\S}$ \\
2 & $8(13.8)$ & $41(16.1)$ & \\
3 & $14(24.1)^{*}$ & $20(7.9)$ & \\
\hline
\end{tabular}

\section{MRI characteristics}

Fazekas Score $2(1)[1-3] \quad 1(1)[0-3] \quad<\mathbf{0 . 0 0 1}^{\#}$

Fazekas Score, n (\%)

\begin{tabular}{lcc}
0 & $0(0.0)$ & $84(33.1)^{*}$ \\
1 & $11(19.0)$ & $134(52.8)^{*}$ \\
2 & $22(37.9)^{*}$ & $28(11.0)$ \\
3 & $25(43.1)^{*}$ & $8(3.1)$ \\
\hline
\end{tabular}

$<0.001^{\S}$

SBI: silent brain ischemia, MRI: magnetic resonance imaging, $\uparrow$ : Student $t$ test, \#: Mann-Whitney U test, §: Chi-square test, *: statistical difference in subgroups, values are presented as $\mathrm{n}(\%)$ for categorical variables, and mean \pm standard deviation or median (interquartile range) [minimum-maximum] for numerical variables

Table 4. Possible predictors of SBI

\begin{tabular}{lccc}
\hline Predictor & OR & 95\% CI & p \\
\hline Age & 0.922 & $0.88-0.95$ & $<\mathbf{0 . 0 0 1}$ \\
Male gender & 0.436 & $0.21-0.89$ & $\mathbf{0 . 0 2 3}$ \\
Gensini score & 0.989 & $0.98-1.00$ & $\mathbf{0 . 0 1 4}$ \\
\hline
\end{tabular}
shows the logistic regression analysis in which possible predictors are presented

\section{DISCUSSION}

In this study we examined the relationship between atherosclerotic coronary artery involvement and asymptomatic cerebrovascular processes, namely SBI and ischemic microangiopathic changes in white matter. It was demonstrated that extend of CAD expressed by Gensini score was associated both with SBI and microangiopathic involvement in brain expressed by Fazekas scores. It was also revealed that coronary atherosclerosis was closely associated with SBI that was located mainly in frontal area. In clinical terms, clinicians need to take into account that the brain parenchyma has higher risks for development of silent white matter vascular injury and SBI in CAD patients with high Gensini scores.

This study clearly depicted the clinical importance of detecting the SBI lesions with cranial MRI in the multivessel CAD even if they have no symptoms of stroke. The association between brain parenchyma and ischemic diseases in the coronary arteries is indisputable. In patients with both symptomatic cardiac disease and CAD, the brain parenchyma is at risk of embolic or occlusive processes. CAD is an important predictive factor of SBI and stroke. Like in the current study, existing research has determined that with age, CAD is an important risk factor in the

Table 3. Localizations and incidence of SBI lesions in MRI

\begin{tabular}{lcc}
\hline Localization & $\mathbf{n}(\boldsymbol{\%})$ & Dimension $(\mathbf{m m})$ \\
\hline Deep White Matter & $23(39.7)$ & $6.24 \pm 2.01$ \\
$\quad$ Frontal & $6(10.3)$ & $4.36 \pm 1.07$ \\
$\quad$ Parietal & $3(5.2)$ & $6.86 \pm 2.83$ \\
$\quad$ Occipital & & \\
Periventricular & $15(25.9)$ & $6.82 \pm 3.02$ \\
$\quad$ Frontal & $5(8.6)$ & $6.80 \pm 4.57$ \\
$\quad$ Occipital & $3(5.2)$ & $5.40 \pm 1.32$ \\
Basal Ganglia & $2(3.4)$ & $3.36 \pm 2.88$ \\
$\quad$ Putamen & $1(1.7)$ & 6.80 \\
$\quad$ External capsule & Internal capsule & \\
SBI: silent brain ischemia, MRI: magnetic resonance imaging, values are presented as
\end{tabular}
SBI: silent brain ischemia, MRI: magnetic resonance imaging, values are presented as
$\mathrm{n}(\%)$ for categorical variables, and mean \pm standard deviation for numerical variables

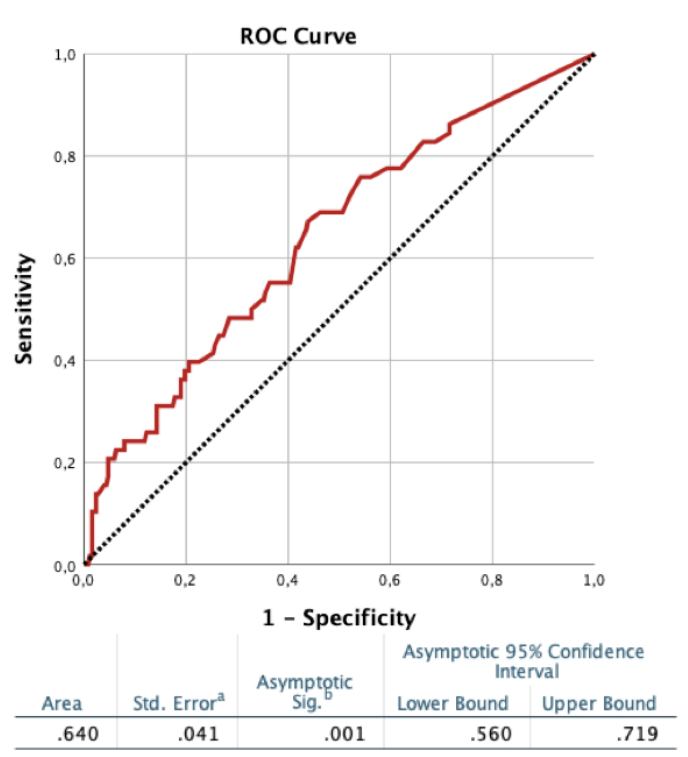

Figure 3. ROC analysis shows the diagnostic performance of Gensini score for predicting SBI lesions. ROC: receiver operating characteristic, SBI: silent brain ischemia 
formation of SBI in the brain $(13,14)$. Coronary atherosclerotic calcifications are also known to be an independent variable in the etiopathogenesis of stroke (15). It was also shown that there is a close relationship between impaired glucose intolerance and CAD (16).

In the literature epidemiological studies have shown that the prevalence of SBI is approximately $10-20 \%$ and that it has an annual incidence of approximately $3 \%$ (17). No study has determined the exact reason explaining why the SBIs develop or why they remain. It is also an argument whether they are silent or not, some of the authors have suggested that the disorder's silence may be due to its chronic impact or appearance in non-strategic areas (18). While evaluating the localization of lesions, it was shown here in that the deep white matter was the most affected area in the brain. The most frequent localizations of SBI lesions were presented in the deep white matter and periventricular white matter of frontal lobes. This supports the reported findings that deep white matter and frontal lobes are more prone to develop SBI lesions. It also might be explained by the locations of lesions why the neurocognitive and neurophysciatric symptoms are more frequent in patients with SBI lesions (19).

In addition to the studies in the literature, the current study revealed the obvious relationship between the SBI lesions and high grade Fazekas white matter lesions. Previous studies have defined leukoaraiosis (or microangiopathic ischemic gliosis) as incomplete ischemia that is caused by small vessel stenosis and led to microangiopathic ischemic disease. This is thought to be due to age-related chronic arteriolosclerosis resulting from long-term hypertension and ischemia caused by arterial stenosis $(20,21)$. The relationship between microvascular disease in brain and deep white matter lesions is also expressed in the Fazekas classification. As an example, the present study demonstrated the increased risk of SBI in deep white matter lesions, especially in those that received ratings of 2 or 3 on the Fazekas scale. This suggests that microvascular disease of brain tend to coexist with SBI lesions. Thus, in their studies Zhang et al. (22) showed that white matter lesions in the brain with high grade Fazekas scale is an independent factor for SBI lesions. As such, intracranial arteriolosclerosis, which can be defined as small vascular disease, can indirectly reveal the presence of CAD (23).

The current study also indicated that CAD should be considered to be a strong predictor of SBI, especially in patients with 3-VD or with high Gensini scores. In addition, Hermann et al.'s (15) work determined that CAD was an independent variable for stroke. Lee et al. (24) also showed that hypertension is an independent predictor of SBI. As in the current study, Hoshide et al. (25) also noted that the likelihood of SBI in CAD was significantly higher in patients with 3-VD. However, unlike Hoshide et al.'s work, the present study also used Gensini scoring to assess CAD. Gensini scoring is a method that demonstrates CAD, stenosis occlusion, and the burden of CAD. By applying this method, the current study revealed a significant statistical relationship between SBI and Gensini scoring. As a result, it would be accurate to suggest that high Gensini score can be predictive of SBI lesions in asymptomatic patients.

MRI is the essential modality for diagnosis of the SBI's. FLAIR is the main sequence of the MRI which can differentiate SBI from the enlarged perivascular spaces which constitute the primary differential diagnosis. SBI's have peripheral hyperintense gliotic rim conversely to perivascular spaces on the FLAIR images. Although SBIs do not have any predictable anatomic localization, enlarged perivascular spaces have well defined anatomic locations and these lesions can be divided into three main types due to their localizations (26).

The current study determined that age, male gender and Gensini score were independent predictors of SBI. Existing literature has also shown that the development of $\mathrm{SBI}$ is powerfully linked to age $(13,17)$. In accordance with previous studies, the current study determined a strong association between SBIs and age. As with a previous work (27), the present study revealed a statistically higher incidence of high-risk cases in males. In their metaanalysis, Fanning et al. (4) identified several strong predictors of SBI, such as age, hypertension, carotid artery disease, and metabolic syndrome. While this study found CAD to be a likely predictor of SBI, it identified gender, smoking, and alcohol as poor predictors of SBI.

The current study found no statistical significant differences in hypertension between the SBI and the nonSBI groups. While it is clear that there is a significant statistical difference in hypertension between SBI patients when compared to the normal population, the current study group consisted of patients with worse cardiovascular risk profile. For this possible reason, there was no statistically significant difference in hypertension between the present study's SBI group and normal non-SBI groups. Retrospective study design was the main limitation of the study.

\section{CONCLUSION}

In conclusion, although SBI lesions are asymptomatic, they potentially may led to brain deterioration and future loss in neurological function. For these reasons, diagnosis is vital. In patients with $\mathrm{CAD}$, it is necessary to evaluate the presence of SBI with cranial MRI examinations, especially in elderly male patients with multivessel (3-VD) involvement and high Gensini scores, regardless of presence of any stroke symptoms.

Ethics Committee Approval: The study was approved by the Ethics Committee of Namık Kemal University Faculty of Medicine (30.11.2017, 2017/94/10/09).

Conflict of Interest: None declared by the authors.

Financial Disclosure: None declared by the authors.

Acknowledgements: None declared by the authors.

\section{REFERENCES}

1. Fisher CM. Lacunes: small, deep cerebral infarcts. Neurology. 1965;15:774-84.

2. Vermeer SE, Longstreth WT Jr, Koudstaal PJ. Silent brain infarcts: a systematic review. Lancet Neurol. 2007;6(7):611-9.

3. Kwon HM, Kim BJ, Lee SH, Choi SH, Oh BH, Yoon BW. Metabolic syndrome as an independent risk factor of silent brain infarction in healthy people. Stroke. 2006;37(2):466-70. 
4. Fanning JP, Wong AA, Fraser JF. The epidemiology of silent brain infarction: a systematic review of population-based cohorts. BMC Med. 2014;12:119.

5. Bokura H, Kobayashi S, Yamaguchi S, Iijima K, Nagai A, Toyoda G, et al. Silent brain infarction and subcortical white matter lesions increase the risk of stroke and mortality: a prospective cohort study. J Stroke Cerebrovasc Dis. 2006;15(2):57-63.

6. Fanning JP, Wesley AJ, Wong AA, Fraser JF. Emerging spectra of silent brain infarction. Stroke. 2014;45(11):3461-71.

7. Longstreth WT Jr, Dulberg C, Manolio TA, Lewis MR, Beauchamp NJ Jr, O'Leary D, et al. Incidence, manifestations, and predictors of brain infarcts defined by serial cranial magnetic resonance imaging in the elderly: the cardiovascular health study. Stroke. 2002;33(10):2376-82.

8. Zhu YC, Dufouil C, TzourioC, Chabriat H. Silent brain infarcts: a review of MRI diagnostic criteria. Stroke. 2011;42(4):1140-5.

9. Pardo PJM, Labrador Fuster T, Torres Nuez J. Silent brain infarctions in patients with coronary heart disease. A Spanish population survey. J Neurol. 1998;245(2):93-7.

10. Sullivan DR, Marwick TH, Freedman SB. A new method of scoring coronary angiograms to reflect extent of coronary atherosclerosis and improve correlation with major risk factors. Am Heart J. 1990;119(6):1262-7.

11. Gupta A, Giambrone AE, Gialdini G, Finn C, Delgado D, Gutierrez J, et al. Silent brain infarction and risk of future stroke: a systematic review and meta-analysis. Stroke. 2016;47(3):719-25.

12. Fazekas F, Chawluk JB, Alavi A, Hurtig HI, Zimmerman RA. MR signal abnormalities at $1.5 \mathrm{~T}$ in Alzheimer's dementia and normal aging. AJR Am J Roentgenol.1987;149(2):351-6.

13. Tanaka H, Sueyoshi K, Nishino M, Ishida $M$, Fukunaga R, Abe H. Silent brain infarction and coronary artery disease in Japanese patients. Arch Neurol. 1993;50(7):706-9.

14. Uehara T, Tabuchi M, Mori E. Risk factors for silent cerebral infarcts in subcortical white matter and basal ganglia. Stroke. 1999;30(2):378-82.

15. Hermann DM, Gronewold J, Lehmann N, Moebus S,
Jöckel KH, Bauer M, et al. Coronary artery calcification is an independent stroke predictor in the general population. Stroke.2013;44(4):1008-13.

16. Durakoğlu Z, Öner İ, Kılıç B, Seber SK, Yurtsever H. lmpaired glucose tolerance and aherosclerosis. Sisli Etfal Hastan Tip Bul. 1996;30(3):28-32.

17. Vermeer SE, Den Heijer T, Koudstaal PJ, Oudkerk M, Hofman A, Breteller MM, et al. Incidence and risk factors of silent brain infarcts in the population-based Rotterdam Scan Study. Stroke. 2003;34(2):392-6.

18. Feng C, Bai X, Xu Y, Hua T, Liu XY. The 'silence' of silent brain infarctions may be related to chronic ischemic preconditioning and nonstrategic locations rather than to a small infarction size. Clinics (Sao Paulo). 2013;68(3):365-9.

19. Badrin S, Mohamad N, Yunus NA, Zulkifli MM. A brief psychotic episode with depressive symptoms in silent right frontal lobe infarct. Korean J Fam Med. 2017;38(6):380-2.

20. Pantoni L. Pathophysiology of age-related cerebral white matter changes. Cerebrovasc Dis. 2002;13(Suppl 2):7-10.

21. Xiong YY, Mok V. Age-related white matter changes. J Aging Res. 2011;2011:617927.

22. Zhang C, Wang Y, Zhao X, Wang C, Liu L, Pu Y, et al. Factors associated with severity of leukoaraiosis in first-ever lacunar stroke and atherosclerotic ischemic stroke patients. J Stroke Cerebrovasc Dis. 2014;23(10):2862-8.

23. Chen X, Wen W, Anstey KJ, Sachdev PS. Prevalence, incidence, and risk factors of lacunar infarcts in a community sample. Neurology. 2009;73(4):266-72.

24. Lee SC, Park SJ, Ki HK, Gwon HC, Chung CS, Byun $\mathrm{HS}$, et al. Prevalence and risk factors of silent cerebral infarction in apparently normal adults. Hypertension. 2000;36(1):73-7.

25. Hoshide S, Kario K, Mitsuhashi T, Sato Y, Umeda Y, Katsuki T, et al. Different patterns of silent cerebral infarct in patients with coronary artery disease or hypertension. Am J Hypertens. 2001;14(6 Pt 1):509-15.

26. Kwee RM, Kwee TC. Virchow-Robin spaces at MR imaging. Radiographics. 2007;27(4):1071-86.

27. Cho AH, Kim HR, Kim W, Yang DW. White matter hyperintensity in ischemic stroke patients: it may regress over time. J Stroke. 2015;17(1):60-6. 